The results obtained show that the anaesthetist was statistically significantly the less unreliable a judge of operative blood loss compared with the surgeon. The anaesthetist's estimate coincided with that measured by the machine 20 times; he overestimated 52 cases and underestimated 26 cases.

The frequency of overestimating blood loss by the anaesthetist and by the surgeon is shown in Fig. 1. Of the 52 times that the anaesthetist overestimated blood loss this was within the $0-99 \mathrm{ml}$ on 25 occasions.

The anaesthetist did not underestimate blood loss beyond $1,000 \mathrm{ml}$, whereas the surgeon underestimated up to $2,000 \mathrm{ml}$ (Fig. 2).

\section{Discussion and Conclusion}

Haemophobia is defined as a morbid dread of blood (Dorland's Illustrated Medical Dictionary). To the layman this morbid dread of blood often results in a faint at the sight of blood. Surgeons sometimes suffer from haemophobia in a different way; when the anaesthetist starts blood transfusion during an operation some surgeons regard it as an affront to their surgical skill and thus dislike it. Some anaesthetists have their own kind of haemophobia in that at the slightest sign of blood loss during an operation they immediately start blood transfusion.

Subjective estimation by visual assessment is extremely uncertain and should not be relied on in any but the fittest of adult patients for the simplest operations (Thornton, 1971). The method, however, has the advantage of costing nothing and of being rapid and continuous. Bonica and Lyter (1951), in summarizing the work of 17 other investigators, concluded that the blood loss estimated by the surgeon was always less than that actually measured.
Brockner and Donvig (1969) compared the amount of blood lost during operation, usually estimated by the anaesthetist and the anaesthetic nurse, with the amount of blood determined electrometrically after washing out the blood of the drapes, swabs, and sponges in 216 cases. They concluded that the visual estimation of blood loss during operation (by the anaesthetist and his nurse) was unreliable in many cases. Underestimation was more frequent than overestimation.

In situations where conditions are such that subjective estimation of blood loss is the only practical method of assessing blood loss during an operation the anaesthetist should conjointly with the surgeon make the estimate, but the anaesthetist should remember that his surgical colleague is a less reliable judge.

Thanks are due to my surgical and anaesthetic colleagues and to the anaesthetic nursing staff who took part in this study. Thanks are also due to Mr. Henry Lee and to Miss S. Dawood for the preparation of the charts and the secretarial work respectively. Mr. Lai Yeow Hin, of the medical records unit, University Hospital, gave invaluable help in the statistical analysis of the results.

\section{References}

Bonica, J. J., and Lyter, C. S. (1951). American fournal of Surgery, 81, 496. Brockner, J., and Donvig, M. (1969). Acta Anaesthesiologica Scandinavica, 13,21

Dorland's Illustrated Medical Dictionary, (1965). 24th ed., p. 664. Philadelphia, Saunders.

Endahl, I., and Moller, H. (1952). Acta Chirurgica Scandinavica, 103, 258. Gatch, W. D., and Little, W. D. (1924). Fournal of the American Medica Association, 83, 1075.

LeVeen, H. H., and Rubricius, J. L. (1958). Surgery, Gynecology and Obstetrics, 106, 368

Rustard, H. (1963). Acta Chirurgica Scandinavica, 125, 14.

Thornton, J. A. (1971). General Anaesthesia, ed. T. C. Gray, and J. F. Nunn, 3rd ed., vol. 2 , p. 511. London, Butterworth.

Wangensteen, O. H. (1942). Minnesota Medicine, 25, 783.

Williams, J. A., and Fine, J. (1961). New England fournal of Medicine, 264, 842 .

\title{
Complicated Migraine and Haemoglobin AS in Nigerians
}

\section{BENJAMIN O. OSUNTOKUN, OLABOPO OSUNTOKUN}

British Medical fournal, 1972, 2, 621-622

\section{Summary}

Among 123 Nigerians with migraine seen at one clinic $49(40 \%)$ had complicated migraine, with ophthalmoplegia in 20 and amaurosis or field defects in 13. Haemoglobin AS was found in $60 \%$ of patients with complicated migraine, compared with $20 \%$ of those with simple migraine.

\section{Introduction}

Earlier reports suggested that migraine is uncommon in Africans, and that where it was frequent it seemed rather mild and seldom caused absence from work (Trowell, 1960). In University College Hospital (U.C.H.), Ibadan, the frequency of migraine in the hospital population is 3 per 10,000 (Osuntokun, 1971), which is much lower than the figure of 15 per 10,000 quoted for Caucasians (Merritt, 1967). More than transient neurological defects in the prodromal phase or during or after attack of migrainous headache are fairly uncommon in most reported

\section{University College Hospital, Ibadan, Nigeria}

BENJAMIN O. OSUNTOKUN, M.D., PH.D., M.R.C.P., Professor of Neurology

OLABOPO OSUNTOKUN, M.B., B.S., D.o., Lecturer in Ophthalmology series of patients who suffered from migraine (Merritt, 1967). We have observed a somewhat unusually high frequency of "complicated" migraine in the Nigerians. Our findings are of interest, especially with regard to the relation of such complications to haemoglobinopathy, which is common in several negroid populations.

\section{Patients and Methods}

During 1966-71 we saw 123 Nigerians who suffered from migraine or migrainous neuralgia (Horton's syndrome, cluster headaches). They were evaluated in the neurology clinic, U.C.H., Ibadan; a number of these patients were, in fact, initially seen at the ophthalmology clinic, U.C.H., Ibadan, by one of us (O.O.).

For the purpose of this paper we define "complicated migraine" as migraine with symptoms or manifestations of abnormal neuronal functions, such as amaurosis, ptosis, ophthalmoplegia, other localized weakness, sensory loss, disturbance of speech and equilibrium, or loss of consciousness, and lasting more than one hour, preceding, associated with, or following the headache of migraine.

Apart from detailed clinical, neurological, and ophthalmological assessment, investigations included plain radiographs of chest, cervical spine, and skull, and determination of haematological indices, including haemoglobin electrophoretic fractionation on Whatman's $3 \mathrm{MM}$ chromatographic paper in 
barbitone buffer (Dyke, 1960). In patients with ophthalmoplegic migraine and more persistent neurological defect (duration greater than 24 hours) oral and prednisolone-stressed glucose tolerance tests (interpreted according to generally accepted standard (W.H.O., 1965; Anderson and Friis, 1967)), examination of cerebrospinal fluid, electroencephalography (E.E.G.), and carotid angiography were done to exclude diabetes mellitus and structural intracranial lesions.

\section{Results}

Age and Sex Distribution.-All our patients were under the age of 50 years-3\% were in the first decade, $34 \%$ in the second, $40 \%$ in the third, $21 \%$ in the fourth, and $2 \%$ in the fifth. In the two patients (both women) in the fifth decade at onset migrainous headaches developed soon after the menopause. The percentage distribution with regard to age for males and females separately show no pronounced difference from the above. There were 88 females and 35 males, giving a female to male ratio of 5 to 2 . This ratio was approximately maintained throughout the first four decades of life.

Relation to Socioeconomic Status.-Thirty per cent. of the 123 patients belong to the upper socioeconomic groups (earning above $£ 500$ p.a.).

Family History.-Eighty per cent. of the patients volunteered a family history of periodic "headache" in first-degree relations.

Complicated Migraine.-This, as defined above, was encountered in $49(40 \%)$ of the patients. The age and sex distribution of those with complicated migraine do not show any bias and merely reflect the age and sex distribution in the population with migraine as seen in this study. Of these, 20 had ophthalmoplegic complications-isolated partial palsy of oculomotor nerve in 18, palsy of oculomotor and abducens nerves in one, and palsy of abducens nerve in one. Other complications encountered include total amaurosis (11), visual field defects (2), sensory loss or paraesthesiae (13), vertigo (11), isolated weakness of limbs (4), epilepsy or repeated loss of consciousness (3), dysphasia (3), alexia (1), and agraphia (1). In two patients, both females in the second decade and without audible intracranial or orbital bruits, fundoscopy showed extremely tortuous and intertwining retinal vessels; angiographic investigations were normal. Occasional transient E.E.G. abnormalities suggesting focal cortical lesions were found. In $90 \%$ of the patients the neurological defect disappeared within 24 hours. In only one patient did it persist for more than two weeks, but then eventually cleared up. Of the 13 patients with migrainous neuralgia, only one showed features of complicated migraine-transient unilateral ptosis. No patient had diabetes mellitus or intracranial structural abnormalities.

Distribution of Abnormal Haemoglobin in Patients. - No patient with haemoglobin SS, SC, or AC was seen in this series. The table shows that haemoglobin AS was significantly more frequent in patients with complicated migraine than in those without complicated migraine $\left(\chi^{2}=17.77, P<0.001\right.$ for both sexes, $\chi^{2}=10.55,0.001<P<0.002$ for females, and $\chi^{2}=5.83$, $0.01<\mathrm{P}<0.02$ for males). The frequency of haemoglobin AS in Nigerian patients with migraine is significantly higher than the frequency in normal Nigerian blood donors in U.C.H., Ibadan $\left(\chi^{2}=4.6,0.02<P<0.05\right)$. There is no age effect on the prevalence of haemoglobin AS in patients with migraine or complicated migraine and in normal Nigerians.

Distribution of Haemoglobin AS in 123 Cases of Migraine in Nigerians

\begin{tabular}{|c|c|c|c|c|c|c|c|c|}
\hline & & \multicolumn{2}{|c|}{ Male } & \multicolumn{2}{|c|}{ Female } & \multicolumn{3}{|c|}{ Both Sexes } \\
\hline & & \multirow{2}{*}{$\begin{array}{l}\text { Total } \\
\text { No. }\end{array}$} & \multirow{2}{*}{$\begin{array}{l}\text { No. } \\
\text { with } \\
\text { AS }\end{array}$} & \multirow{2}{*}{$\begin{array}{l}\text { Total } \\
\text { No. }\end{array}$} & \multirow{2}{*}{$\begin{array}{l}\text { No. } \\
\text { with } \\
\text { AS }\end{array}$} & \multirow{2}{*}{$\begin{array}{l}\text { Total } \\
\text { No. }\end{array}$} & \multicolumn{2}{|c|}{ With AS } \\
\hline & & & & & & & No. & $\%$ \\
\hline $\begin{array}{l}\text { Complicated migraine } \\
\text { Uncomplicated migraine }\end{array}$ & $\because$ & $\begin{array}{l}15 \\
20\end{array}$ & $\begin{array}{l}9 \\
3\end{array}$ & $\begin{array}{l}34 \\
54\end{array}$ & $\begin{array}{l}20 \\
12\end{array}$ & $\begin{array}{l}49 \\
74\end{array}$ & $\begin{array}{l}29 \\
15\end{array}$ & $\begin{array}{l}60 \\
20\end{array}$ \\
\hline \multicolumn{6}{|c|}{ Normal Nigerian blood donors in U.C.H., Ibadan (Esan, 1970) } & 3,002 & 781 & 26 \\
\hline
\end{tabular}

\section{Discussion}

Migraine is not uncommon in the Nigerian. Thirty per cent. of our patients belonged to the upper socioeconomic groups, which form only about $1 \%$ of the population in Nigeria (Nigeria Census, 1963). These subjects are more likely to report to hospital, complaining of headache. This is probably true of the Caucasians, for it has been shown that migraine in the Caucasians is in no way correlated to intelligence, and that the higher prevalence among patients in the high socioeconomic groups can be explained by the hypothesis that patients in these groups who suffered from migraine are more likely to seek medical aid (Waters, 1971).

The sex ratio among Nigerian patients who suffer from migraine is similar to that reported for the Caucasians (Merritt, 1967).

It can be explained pathophysiologically that the presence of sickling trait (haemoglobin AS) will contribute to the expression and morbidity of migraine in Nigerians, among whom the frequency of haemoglobin $\mathrm{S}$ is about $25 \%$ (Watson-Williams, 1965; Esan, 1970). Occlusive disease of the intracranial vessels and other forms of cerebrovascular accidents are known to occur in sickle-cell crises in those with haemoglobin SS (Adeloye and Odeku, 1970) but are extremely rare in those with haemoglobin AS. Vasoconstriction (as may occur in migraine) and resultant stasis will reduce the oxygen concentration of the tissues and will encourage sickling. Such sickling will promote transient vaso-occlusion and possibly microinfarctions in the patients with haemoglobin AS who, although usually symptomless, apart from being susceptible to painless haematuria due to ischaemic renal papillitis, may develop symptons under conditions causing reduced tension of oxygen in the tissues as may be induced by vasoconstriction that occurs in migraine. In migraine vasoconstriction per se can cause cerebral infarction (Guest and Woolf, 1964; Myhrman, 1967).

It is notable that other haemoglobin electrophoretic types such as SC and SS are not represented in our series of Nigerian patients with complicated migraine, if in fact the theoretical explanation that migrainous vasoconstriction causes hypoxia and sickling is true. In the Nigerian population the frequency of haemoglobin SS is only of the order of $1-2 \%$, and that of SC is even lower (G. J. F. Esan, personal communication, 1972). Besides, many patients with haemoglobin SS disease do not survive to adult life. A larger series than ours will therefore be needed to substantiate the association between haemoglobin SS disease and complicated migraine.

We thank the department of haematology, U.C.H. Ibadan, for haemoglobin electrophoretic fractionation; Professor E. L. Odeku and Dr. A. Adeloye, of the neurosurgical unit, department of surgery, for carotid angiographic investigation on some of these patients; and Professors A. O. Lucas and L. Luzzatto for their useful criticisms.

Requests for reprints should be sent to Dr. B. O. Osuntokun, Department of Psychiatry and Neurology, University College Hospital, Ibadan, Nigeria.

\section{References}

Adeloye, A., and Odeku, E. L. (1970). African Fournal of Medical Sciences, $1,33$.

Anderson, O. O., and Friis, T. (1967). Acta Medica Scandinavica, 181, 535. Dyke, S. C. (1960). Recent Advances in Clinical Pathology. London, Churchill. Esan, G. J. F. (1970). British Fournal of Haematology, 19, 47.

Guest, I. A., and Woolf, A. L. (1964). British Medical fournal, 1, 225

Merritt, H. H. (1967). Textbook of Neurology, 4th edn., p. 745 . London, Kimpton.

Myhrman, G. (1967). Acta Medica Scandinavica, 181, 583.

Osuntokun, B. O. (1971). Fournal of the Neurological Sciences, 12, 417.

Trowell, H. C. (1960). Non-infective Diseases in Africa, p. 268. London, Arnold.

Waters, W. E. (1971). British Medical Fournal, 2, 77.

Watson-Williams, E. J. (1965). In Abnormal Haemoglobins in Africa, ed. J. H. P. Jonxis, p. 213. Oxford, Blackwell, Scientific.

World Health Organization (1965). Technical Report Series, No. 310. 